\title{
Flood Risk Assessment and Its Vulnerability in Coastal Villages, Central Halmahera District - North Maluku
}

\author{
Mohammad Ridwan Lessy ${ }^{1}$ \\ Marine Science Department \\ Universitas Khairun \\ Ternate, Indonesia \\ 1mrlessy8375@gmail.com
}

\author{
Nani Nagu ${ }^{2}$, Muhammad Rizal ${ }^{4}$ \\ Civil Engineering \\ Universitas Khairun \\ Ternate, Indonesia \\ ${ }^{2}$ nani.nagu09@gmail.com, ${ }^{4}$ adams.rizal@yahoo.co.id
}

\author{
Nurhalis Wahiddin ${ }^{3}$ \\ Marine Resources Management \\ Universitas Khairun \\ Ternate, Indonesia \\ ${ }^{3}$ nurhalisw@gmail.com
}

\begin{abstract}
Floods that occurred in Central Halmahera district had given a significant impact on environmental damage. This study aims to assess the risk level of flood and calculate vulnerability in study areas. The vulnerability will calculate based on social, economic and environmental aspects. Furthermore, the flood risk will be shown on risk map that refers to hazard index, and vulnerability index. The hazard index parameter was based on the high, the duration and the frequency of the flood. The vulnerability index parameter was based on the number of peoples, the sex ratio, vulnerability peoples, poverty ratio, number of facilities, and natural resources. Those parameters were analyzed by using guidelines for disaster risk assessment authorized by the National Disaster Management Agency. The result shows that the total vulnerability index found six villages at a high category and nine villages at the moderate category. Meanwhile, the risk map displays that almost all the village areas have a flood risk level varies from low to high risk. Low-risk areas are generally located in high altitudes. While high-risk areas are dominated on village areas.
\end{abstract}

Keywords-flood risk analysis; vulnerability analysis; central Halmahera

\section{INTRODUCTION}

Floods are a natural section of the hydrological cycle. Nevertheless, they one of the most common hazards in the world that have the potential to cause fatalities, displacement of people, livelihood and property destruction and damage to the environment which may also severely endanger the economic development [1][2]. Similarly, the flood had been a massive disaster that occurred in Central
Halmahera district. The floods occurred in this area has been increased in the last ten years. The flood also led to a big impact on infrastructure, human, and environmental [3].

Actually, floods hit vulnerable areas basically due to human activities and natural events [4][5]. Land use changes and environmental degradation caused by deforestation and illegal logging are human activities that respond to flood events. While, natural events such as highly rainfall, sea level rise, storms, due to climate change are the trigger to flood. According to increasing rainfall due to future climate change is expected to increase the intensity of flood events [6][7]. Rainfall trends projection in Indonesia conducted by the Meteorology, Climatology and Geophysics Agency shows that rainfall will increase for period December-January-February (DJF) in 2032-2040. This escalation will occur in almost all of Java and eastern Indonesia. While sea level rise in Indonesia increased to 1.6 $\mathrm{mm}$ /year since 1960 and jumped to $7 \mathrm{~mm}$ /year from 1993 [8]. Of course, it has an impact on flood events in the future in Eastern Indonesia including Central Halmahera District.

Nevertheless, Floods have a temporal and geographic footprint that identifies the duration of impact and its extent on the Earth's surface. Therefore improve technology currently in GIS, remote sensing and hydraulic modelling technology have been extensively used in formulating models used widely in the world in terms of disaster risk reduction [9][10]. This technology has several advantages such as easy to apply, inexpensive, can modify as environmental modelling, and cover a wide area [11].

Risk assessment and mapping of disaster-prone areas using spatial analysis are intended to obtain an overview of the level, extension and distribution of hazard in an area. 
Disaster risk map includes three main stages of hazard, vulnerability, and risk. Therefore, this study combines all aspects on flood and develops information technology to map and calculate risk indices in the study area. Actually, the Indonesian government through the National Disaster Management Agency have been compiled the regulation No 2/2012 about general guidelines for disaster risk assessment. This guideline was useful for providing the guidance for each region in terms of assessing each risk disasters in their area and optimizing the implementation of disaster management in an area with focusing on the treatment of several risk parameters with a clear basis and measure. Hence we hope that this study can be applied by all stakeholders to reduce the risk of flood hazard and to arrange the strategic plan in the future.

\section{MATERIAL AND METHOD}

\section{A) Study Sites}

Geographically, Central Halmahera district is a part of North Maluku Province with located between $0^{\circ} 45^{\prime} \mathrm{N}$ $0^{\circ} 15^{\prime} \mathrm{S}$ and $127^{\circ} 45^{\prime} \mathrm{E}-129^{\circ} 26^{\prime} \mathrm{E}$. The district includes $8,381.48 \mathrm{Km}^{2}$ where consist of $27 \%$ land area and $73 \%$ ocean. Administratively, it covers 10 sub-districts and 61 villages. The map of study sites is shown in Fig 1.

From topographic aspect, Central Halmahera district located in the Mandala physiographic of Halmahera Island, which is mostly mountainous areas with steep slopes with deep river incision. Partly of this area is morphologically karst. The physiographic conditions of the main island in Central Halmahera district vary greatly from the coast, mainland, and hills to mountainous areas [12].

Here are many mining activities carried out in the Central Halmahera district. Nickel in Kipai Village, Banemo, Peniti Patani District and North Patani are still in the preparation stage. 7,000 hectares held by PT. Recobana Mineral Resources are in the mining process. Nickel in Lelilef Village, Gemaf are still in the exploration stage, covering an area of 54,000 hectares managed by PT. Weda Bay Nickel including 13 companies granted permits for activities in protected forests. A number of mining activities also contribute to the increase of flood in this region. This is due to land clearing activities by cutting trees and in slopes areas.

From demographic aspect in the study area based on the data from Statistic Bureau of central Halmahera district shows in 2015 the highest population found on Weda subdistrict with 10.214 people or $19.52 \%$ and the lowest is on West Patani sub-district with 4.406 people or $8.42 \%$. Meanwhile, the number of population in central Weda subdistrict was 5,029 people and in Gemaf Village North Weda sub-district was 974 people [13].

Most of the people in the study area are fishermen due to the location of villages are in the coastal area. Others are the farmer, especially in transmigration location. Other occupations of people found in the study area are civil servants, contractors, miners, and jobless.

Nevertheless, this study only focuses 15 villages on three sub-districts namely North Weda, Central Weda and Weda. Those areas are chosen because they are centres of social economic activities, central of the district government, and the location is close to the mining area. In addition, the topographic of those areas are flatland and most of the villages are coastal villages.

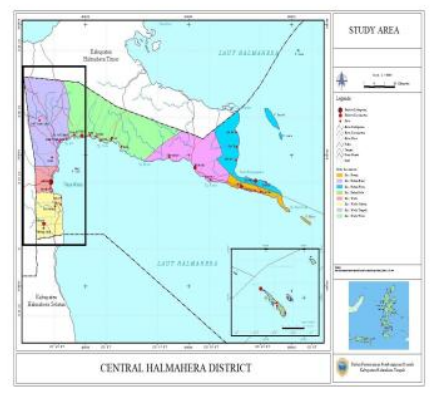

Fig. 1. Study Sites.

\section{B) Dataset and Sources}

Risk assessment and mapping of disaster-prone areas is intended to obtain an overview of the level, extent and distribution of disaster threats spatially in an area. Therefore, in this study, we build disaster risk mapping by mapping the hazard and vulnerability. Next, the disaster risk maps will be generated later through overlay techniques produce a potential map of the flood disaster. The procedure for preparing a risk map is shown on the fig. 2

Both primary and secondary data were used for the study. The primary data were collected by forum group discussion. Respondents in those methods come from a key informant on all stakeholders such as the head of the villages, religious leaders, teachers, fisherman, farmer, private sector and communities. The secondary data is collected from the national and local institution such as; National and regional Disaster Management Agency, Meteorological and Geophysical Agency; Statistics Bureau, and previous research. The secondary data involved in flood risk mapping and vulnerability index included; flood characteristic including inundation area, flood periods, duration and water levels, and levels of danger; geographical information including topography and land use. Hereafter we calculate the social vulnerability index, economic vulnerability index, physical vulnerability index, and environmental vulnerability index [14]. Those indices use to assess the vulnerability index. The data collected for social vulnerability index including population density, sex ratio, disability people, and age distribution. While the data for economic vulnerability index involve an area of productive land and income contribution. Next, the needed data to complete the physical vulnerability index is public facilities, important facilities, and housing; and 
environmental vulnerability index including protected forest, natural forest, mangroves and shrubs.

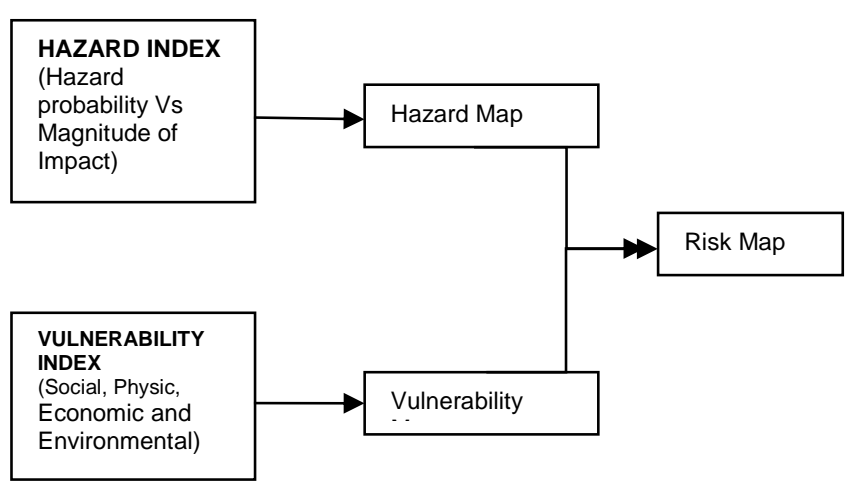

Fig. 2. Procedure for Generating Risk Map.

\section{C) Data Analysis}

Many experts agreed that risk is the product of a hazard and its consequences [15]. Related to disaster, risk can be defined when people are harmed and/or their belongings damaged. Hazard may be defined as a source of potential harm or a threat or condition that may cause vulnerability of life or initiate any failure to the natural and human systems [16][17]. So the risk can be proposed in a simple equation;

$$
\text { Risk Index } \sim H * V
$$

Where; $R$ is Disaster Risk; $H$ is Hazard; The frequency (possibility) of certain disasters tends to occur with certain intensity at a particular location. $V$ is Vulnerability: Expected vulnerability (impact) in a particular area a particular case of disaster occurs with a certain intensity. This variable calculation is usually defined as exposure (population, assets, etc.) multiplied by sensitivity for a specific intensity of disaster. Vulnerability assessments vary in the balance of social, economic and political characteristics included and in the extent to which environmental and ecological assets are included [16]. Therefore, a vulnerability in this study will divide into four indices; People exposed index, Economic vulnerability index, Physic vulnerability index, and Environmental vulnerability index. From this equation, can we say that the risk $(R)$ is comparable to a hazard $(H)$ and vulnerability $(V)$. Risk assessment in the context of this research is a product of the probability of a location affected by a flood event and the vulnerability of the people who live in those areas.

TABLE I. THE INDICATOR OF HAZARD INDEX AND ITS CRITERIA

\begin{tabular}{|c|c|c|c|c|c|}
\hline \multirow{2}{*}{ Indices } & \multirow{2}{*}{ Indicators } & \multicolumn{3}{|c|}{ Index scores } & \multirow{2}{*}{ Multiplier } \\
\hline & & Low & Moderate & High & \\
\hline $\begin{array}{l}\text { Hazard } \\
\text { Index }\end{array}$ & $\begin{array}{l}\text { Flood Prone Area } \\
\text { Zoning Map } \\
\text { (sources; Public } \\
\text { Work Dept.; } \\
\text { National } \\
\text { Geospatial } \\
\text { Agency) }\end{array}$ & $0.76 \mathrm{~m}$ & $\begin{array}{l}0.76-1.5 \\
\mathrm{~m}\end{array}$ & $>1.5 \mathrm{~m}$ & 1.0 \\
\hline
\end{tabular}

TABLE II.

THE INDICATOR OF VULNERABILITY INDEX AND ITS CRITERIA

\begin{tabular}{|c|c|c|c|c|c|}
\hline \multirow{2}{*}{ Indices } & \multirow{2}{*}{ Indicators } & \multicolumn{3}{|c|}{ Index scores } & \multirow{2}{*}{ Multiplier } \\
\hline & & Low & Moderate & High & \\
\hline \multirow{19}{*}{$\begin{array}{l}\text { Vulnerability } \\
\text { Index }\end{array}$} & \multicolumn{5}{|c|}{ Social vulnerability index } \\
\hline & $\begin{array}{l}\text { Population } \\
\text { Density }\end{array}$ & $\begin{array}{c}<500 \\
\text { people } \\
/ \mathrm{km} 2\end{array}$ & $\begin{array}{c}500- \\
1000 \\
\text { people } \\
/ \mathrm{Km} 2\end{array}$ & $\begin{array}{l}>1000 \\
\text { people } \\
/ \mathrm{Km} 2\end{array}$ & 0.6 \\
\hline & Sex ratio & $<20 \%$ & $20-40 \%$ & $>40 \%$ & 0.1 \\
\hline & Poverty Ratio & $<20 \%$ & $20-40 \%$ & $>40 \%$ & 0.1 \\
\hline & $\begin{array}{l}\text { Disabled } \\
\text { People } \\
\end{array}$ & $<20 \%$ & $20-40 \%$ & $>40 \%$ & 0.1 \\
\hline & $\begin{array}{l}\text { Age Group } \\
\text { Ratio }\end{array}$ & $<20 \%$ & $20-40 \%$ & $>40 \%$ & 0.1 \\
\hline & \multicolumn{5}{|c|}{ Economic Vulnerability Index } \\
\hline & $\begin{array}{l}\text { Productive } \\
\text { Land }\end{array}$ & $\begin{array}{l}<50 \\
\text { million }\end{array}$ & $\begin{array}{l}50-200 \\
\text { million }\end{array}$ & $\begin{array}{l}>200 \\
\text { million }\end{array}$ & 0.6 \\
\hline & GRDP & $\begin{array}{l}<20 \\
\text { million }\end{array}$ & $\begin{array}{l}20-40 \\
\text { million }\end{array}$ & $\begin{array}{c}>40 \\
\text { million }\end{array}$ & 0.4 \\
\hline & \multicolumn{5}{|c|}{ Physic Vulnerability Index } \\
\hline & House & $\begin{array}{l}<400 \\
\text { million }\end{array}$ & $\begin{array}{l}400-800 \\
\text { million }\end{array}$ & $\begin{array}{l}>800 \\
\text { million }\end{array}$ & 0.4 \\
\hline & $\begin{array}{l}\text { Public } \\
\text { facilities }\end{array}$ & $\begin{array}{l}<500 \\
\text { million }\end{array}$ & $\begin{array}{c}500 \\
\text { million- } 1 \\
\text { Billion }\end{array}$ & $\begin{array}{c}>1 \\
\text { Billion }\end{array}$ & 0.3 \\
\hline & $\begin{array}{l}\text { Critical } \\
\text { facilities }\end{array}$ & $\begin{array}{l}<500 \\
\text { million }\end{array}$ & $\begin{array}{c}500 \\
\text { million- } 1 \\
\text { Billion }\end{array}$ & $\begin{array}{c}>1 \\
\text { Billion }\end{array}$ & 0.3 \\
\hline & \multicolumn{5}{|c|}{ Environmental Vulnerability Index } \\
\hline & $\begin{array}{l}\text { Protected } \\
\text { Forest } \\
\end{array}$ & $\begin{array}{l}<20 \\
\mathrm{Ha}\end{array}$ & $20-50 \mathrm{Ha}$ & $>50 \mathrm{Ha}$ & 0.3 \\
\hline & Natural Forest & $\begin{array}{l}<25 \\
\mathrm{Ha}\end{array}$ & $\begin{array}{c}25-75 \\
\mathrm{Ha} \\
\end{array}$ & $>75 \mathrm{Ha}$ & 0.3 \\
\hline & Mangrove & $<10 \mathrm{Ha}$ & $10-30 \mathrm{Ha}$ & $>30 \mathrm{Ha}$ & 0.1 \\
\hline & Shrubs & $\begin{array}{l}<10 \\
\mathrm{Ha}\end{array}$ & $10-30 \mathrm{Ha}$ & $>30 \mathrm{Ha}$ & 0.1 \\
\hline & Swamp & $<5 \mathrm{Ha}$ & $5-20 \mathrm{Ha}$ & $>20 \mathrm{Ha}$ & 0.2 \\
\hline
\end{tabular}

The flood risk assessment of the study area was carried out based on the hazard and vulnerability assessment of some indicators. The first step involves the identification of the most important indicators (that is hazard and vulnerability indices) influencing flood risk. Total vulnerability index value obtained from the sum of all index values. To calculation the all indices value used the formulas [18]:

Social Vulnerability Index $(S V I)=$ $\{(0.6 * \log ($ Population Density/0.01)/log $(100 / 0.01)\}+$ $(0.1 *$ Sex ratio $)+(0.1 *$ Poverty Ratio $)+(0.1 *$ Disabled People $)+(0.1 *$ Age Group Ratio $)$

Economic Vulnerability Index $($ EVI $)=(0.6 *$ Productive Land $)+(0.4 * G D P)$

Physic Vulnerability Index $(P V I)=(04 *$ House $)+(0.3 *$ Public Facilities $+(0.3 *$ Critical facilities $)$

(4)

Environmental Vulnerability Index $($ EnVI $)=(03 *$

Protected forest $)+(0.3 *$ natural forest $)+(0.1 *$ Mangrove $)$ $+(0.1 *$ shrub $)+(0.2 *$ Swamp $)$

(5) 
Vulnerability Index $(V I)=(0.4 * S V I)+(0.25 * E V I)+(0.25 *$ $P V I)+(0.1 * E n V I)$

(6)

The second step is transferring the index value to map use spatial analysis. The indicators and their score that used to calculate hazard and vulnerability indices in this study are shown in table 1 and 2 . In this analyses, we refer to expert knowledge and empirical data on flood damages and then expressed on a scale between 0 (no loss at all) and 1 (total loss) however the category divided in three class; low $=0.0$ 0.33 ; moderate $=0.34-0.67$, and high $=0.68-1.0$.

Once the overall vulnerability is calculated, they were linked as attributes to the vector polygon shape of each village and then converted into a raster format to generate a vulnerability map.

\section{RESUlT AND DISCUSSION}

\section{A) History of Flood Disaster in Study Sites}

Flood is defined as the inundation of water in an area for a certain time or overflowing runoff, whose volume exceeds the drainage capacity of the drainage system or river. Basically, flooding is a product of the watershed system due to the physical condition of the watershed and the intensity of excessive rainfall. In certain return periods, if high rainfall cannot seep into the soil, cannot be stored in vegetation, and the volume of water exceeds the capacity of the river channel due to the inability of the watershed function, then more rainwater becomes the surface flow and overflows into the surrounding area.

All stakeholders in focus discussion group state that flooding at the study sites is a massive disaster and occurs every year. It generally reaches the peak period on the rainy season between May - October. Based on rainfall data from the rainfall station at Wosea, the average rainfall from 2001 - 2014 around the study area was 87.7 - $354.5 \mathrm{~mm}$ per year with the number of rainy days 7 - 20 days [19]. Meanwhile, the data from Regional Disaster Management Agency of North Maluku Province shows that flooding occurred in this district due to the overflowing of several rivers that flowed around the village area such as Seslewisini river, Ake Sake rivers in Gemaf; Kobe River and Ake Dome in Lelilef Waibulen village, Lelilef Sawai village and Sawai Itepo village; and Ake Kobe, Ake Saloi, Ake Yanges, Ake Jira and Talent in the Kobe transmigration area [20].

Furthermore, the community said that in the last ten years there has been a severe flood occurred. On September 2011, the flash flood occurred in Weda sub-district. The water level reached two meters caused all residents fled. In addition to soaking up government-owned facilities, overall floods also submerged 559 houses. Then in 2016 and 2017 , the flood occurred in July in Central Weda and Weda subdistricts. Flood in these locations due to heavy rain caused the volume of water in the Akejira River rise and overflow. The height of the flood is estimated to reach 2 meters so that almost all residents' housing was damaged and even causes the hospital was closed [21]. The flood has also caused losses in rice production. According to interviews at the Kobe Trans area, previously rice production could reach 5 tons/ha, but after a flood several times, rice production decreased to 2.5 tons/ha.

\section{B) Hazard Index}

The results of the analysis of flood-prone areas at the study site were constructed from the land slope, elevation, soil texture, drainage, rainfall, land-use and river buffers. The slope and elevation are the important factors that influenced flooding in this study. The slope is strongly correlated to both the volume and the velocity of the surface runoff, as well as the infiltration to the groundwater. Flat areas flood quicker than inclined areas where runoff flows further down [22]. Refers to the slope class at the study location, we found that the slope is dominated by steep slope class (45-65\%) (fig.3a). As same as slope, elevation led to water flows from higher to lower elevation, lowland areas are more prone to flooding occurrences. The elevation map was obtained from the reclassification of the Digital Elevation Model (DEM) of the studied river basin. The land elevation in study areas is dominated by areas with altitudes above 100-200 meter from sea level (fig. 3b).
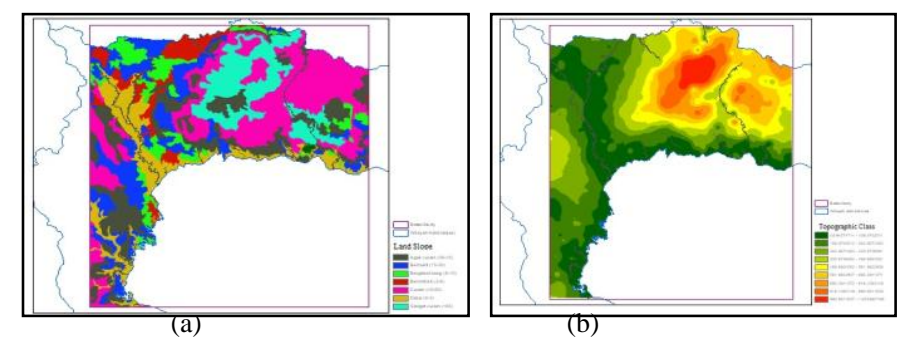

Fig. 3. Land Slope and Topographic Class in Study Area.

Furthermore, soil texture and drainage. Both of these aspects are determining the surface run-off and infiltration. Based on Soil Texture Map, it can be seen that the broadest class for soil texture is fine grade. Whilst, drainage in the study area shows that it is in a good category. It means that soil can receipt or infiltrate rainfall on the study area. The maps of soil texture and drainage are shown on fig $4 \mathrm{a}$ and $4 b$.

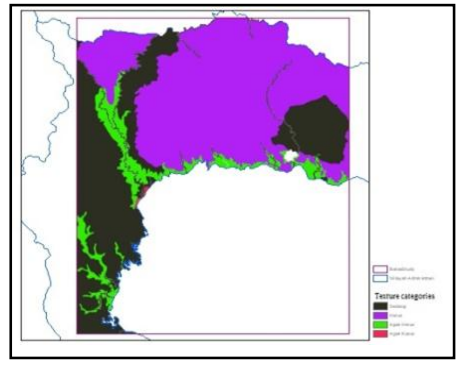

(a)

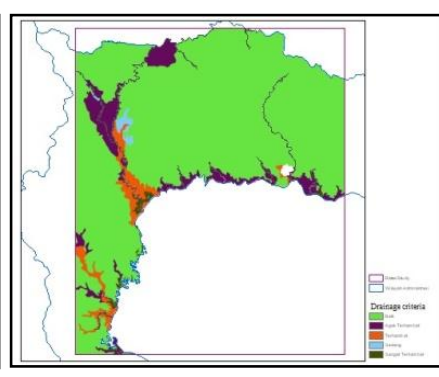

(b)
Fig. 4. Soil Texture and Drainage Class in Study Area. 
The next aspects are land cover and rainfall. Land covering has an essential role in flood disaster. Land cover such as forests, shrubs, plantations, settlements, and mangrove forests are useful to protect soil texture and absorb the run-off. But in open space without vegetation, the flood will in high risk due to the increase of run-off. The result shows that land cover in the study area is dominated by forest $(75 \%)$. The land cover map is shown on fig.5a. Whereas rainfall determined using spatial distribution. This criterion was found using the spline interpolation method in order to also take into account the allocation of stations in the studied area. The result shows that in the study area the rainfall is categorized into two classes, namely humid class (2000-2500 mm) and wet (2500-3000mm) (fig 5.b).

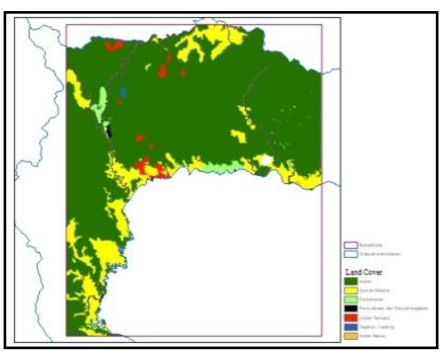

(a)

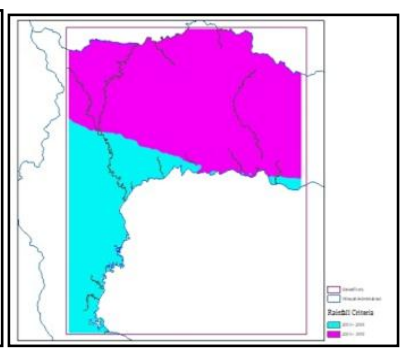

(b)
Fig. 5. Land Cover and Rainfall Categories in Study Area.

The flood hazard map was built use overlay method of all maps. All parameters involved to determine the level of flood hazard is based on score and then reassembled into flood hazard map on the study area. Finally, the calculation of flood hazard index based on all indicators shows that the hazard index in the entire study area was dominated by a low category (Fig.6). The wide area on a low category is 40.725 ha, moderate category 8.616 ha, and low category 6.065 ha.

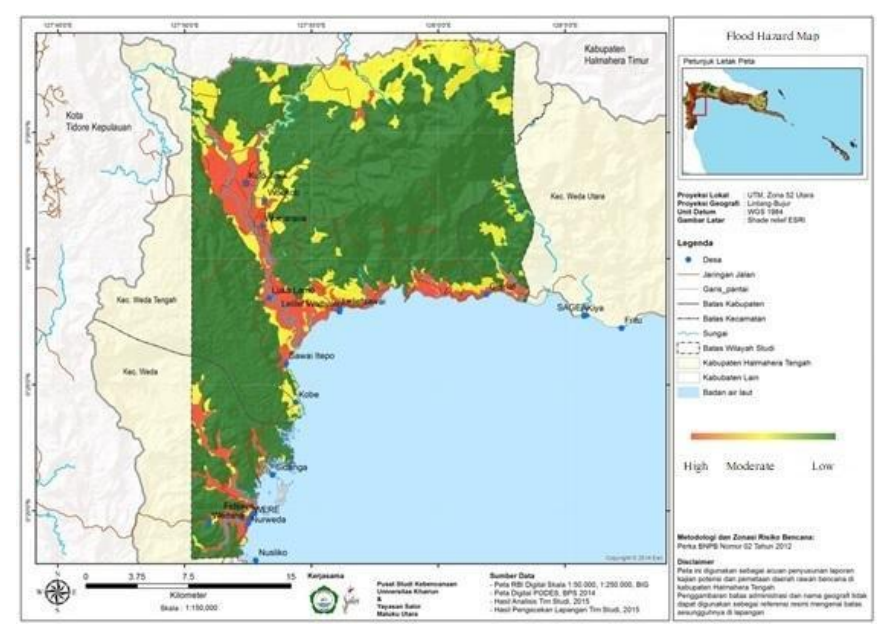

Fig. 6. Flood Hazard Map in the Study Area.

\section{C) Vulnerability Index}

As mention before that, the vulnerability involve several indices such as social, economic, physic, and environmental. Socio-economic vulnerability refers to a common set of indicators to explore differences in social and economic vulnerability between places. A vulnerability has frequently been characterized as a function of both a system's exposure and sensitivity to stress and its capacity to absorb or cope with effects of these stressors [23]. The concept of vulnerability has been a powerful analytical tool for describing states of susceptibility to harm, powerlessness, and marginality of both physical and social systems, and for guiding normative analysis of actions to enhance well-being through reduction of risk [24]. A vulnerability measure focused on human well-being, therefore, incorporates material aspects and outcomes of vulnerability [25].

1) Social Vulnerability Index: The social vulnerability index is focused on exposure of disaster to the population condition. Exposure can be understood as the components that are present at the location where floods can occur. These components can be goods, infrastructure, cultural heritage, agricultural fields and people [26]. While exposure is defined as the likelihood that humans and/or physical items (goods, infrastructure, cultural heritage and agricultural fields) will be impacted by flooding [27].

Determination of the social vulnerability index is calculated from the socio-cultural component in the area that is predicted to be affected by the disaster. This component is obtained from indicators of population density and indicators of vulnerable groups in an area if affected by a disaster. A high density of populations and poverty level are found in coastal areas where the exposure to coastal floods is high [28]. On the one hand, rising sea levels will raise flood levels [29]. The data obtained for the sociocultural component is then divided low, moderate and high categories. This index also shows the number of people who are exposed to disaster threats in an area. Based on the results of the social vulnerability index in all villages, we found that the index value between $0.40-0.47$. This means that all villages state on moderate category (Fig. 7).

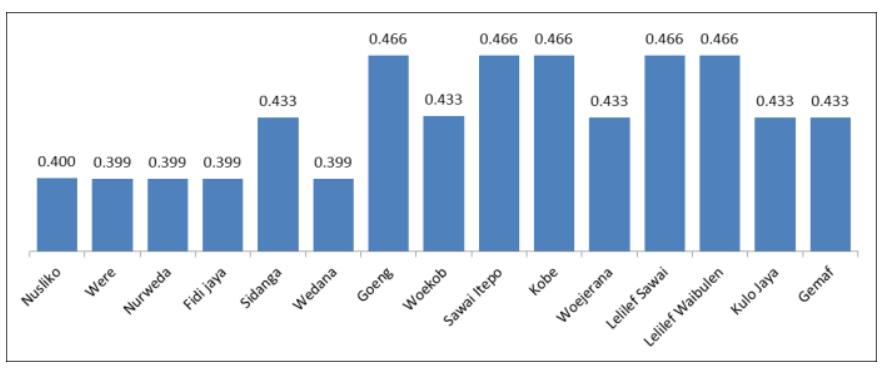

Fig. 7. Social Vulnerability Index in the Study Area.

2) Economic Vulnerability Index: This index is related to the economic resources of the population. The assessment aims to find out whether the resources that the people have 
at this time will be disrupted and affected by a flood disaster. The economic parameters used in calculating this index are productive land in rupiah units and the value of the GDP of Central Halmahera district. The result of the economic vulnerability index is shown on Fig.8. Based on the calculation result, we found that all villages are in high category except Wedana village in the low category. The high Category found in the study area due to the high productivity land where the land used as a farm. On the other hand, GDP of Central Halmahera District is above the index score. This means that when floods occur will affect the high economic aspect in the community.

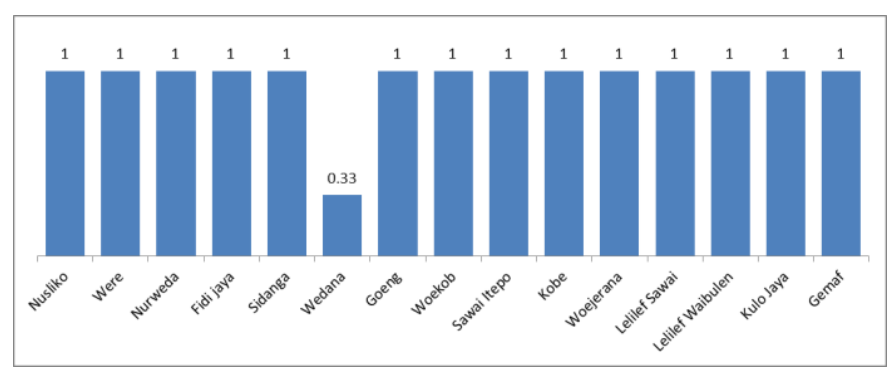

Fig. 8. Economic Vulnerability Index in the Study Area.

3) Physical Vulnerability Index: The physical vulnerability index in the study area was determined based on a number of houses, the availability of buildings/ public facilities, and the availability of critical facilities. Those facilities should be measured due to predicting the damage level when floods occur. Each indicator is calculated based on the value of the building per unit in rupiah. The result shows that Were, Nurweda, Fidi Jaya, Kobe, Lelilef Sawai, Lelilef Waibulen, Kulo Jaya, and Gemaf have index value between $0.68-1.0$ or on high category and others on a moderate category. Those villages have high index value due to the availability of critical infrastructure and facilities such as community health centres, school, mosque, church, and port. The calculation result of physical vulnerability index on the study area is shown fig. 9 .

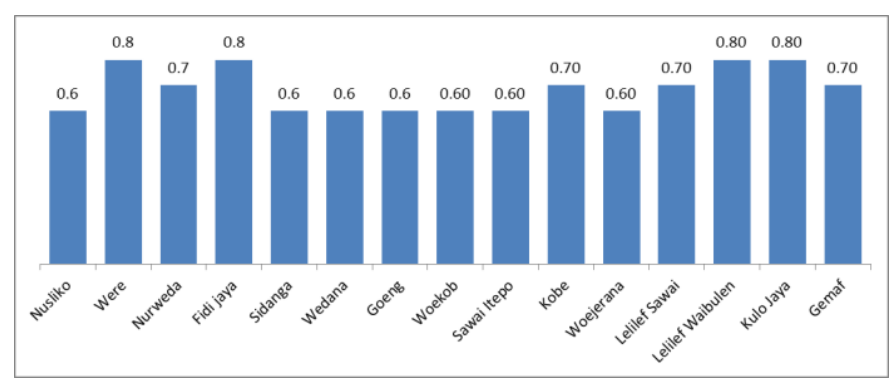

Fig. 9. Physical Vulnerability Index in the Study Area.

4) Environmental Vulnerability Index: Environmental vulnerability index shows how natural assets are threatened by disaster. In this study, the environmental vulnerability index is measured based on the extent of land cover of Protected Forests, Natural Forests, Mangroves, Shrubs, and Swamps. The result points out that Wedana and Goeng are in a low category. Meanwhile Were village, Waekob, and
Woejeranah are in a moderate category, and others villages are in a high category. Environmental vulnerability index on the study area is shown in Fig. 10.

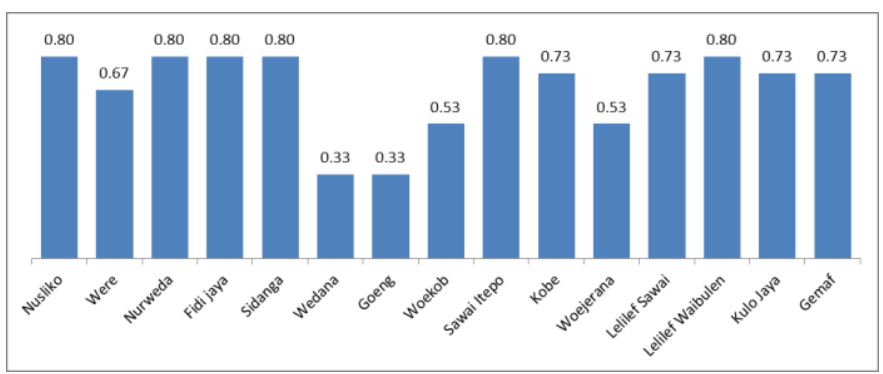

Fig. 10. Environmental Vulnerability Index in Study Area.

5) Total Vulnerability Index: The total vulnerability index is the sum of all vulnerability indices. However, each index has a different percentage in the total vulnerability index. For example, the Social Vulnerability Index has the proportion (0.4) while the Economic Vulnerability Index (0.25) and Physic Vulnerability Index (0.25). It is due to social vulnerability strongly related to human as highest vulnerable than others aspects. The total vulnerability index refers to calculation result shows that six villages in a high category and nine villages at the moderate category. The result of the vulnerability index in the study area is shown in Table III.

TABLE III. TOTAL VULNERABILITY INDEX AND ITS CATEGORY IN STUDY AREA

\begin{tabular}{|c|c|c|c|c|c|c|}
\hline \multirow{2}{*}{ Village } & \multicolumn{4}{|c|}{ Indices Scores } & \multirow{2}{*}{$\begin{array}{l}\text { Total } \\
\text { Score }\end{array}$} & \multirow{2}{*}{ Category } \\
\hline & $S V I$ & $E V I$ & $P V I$ & $E n V I$ & & \\
\hline Nusliko & 0.16 & 0.25 & 0.15 & 0.08 & 0.64 & Moderate \\
\hline Were & 0.16 & 0.25 & 0.20 & 0.07 & 0.68 & High \\
\hline Nurweda & 0.16 & 0.25 & 0.18 & 0.08 & 0.66 & Moderate \\
\hline Fidi jaya & 0.16 & 0.25 & 0.20 & 0.08 & 0.69 & High \\
\hline Sidanga & 0.17 & 0.25 & 0.15 & 0.08 & 0.65 & Moderate \\
\hline Wedana & 0.16 & 0.08 & 0.15 & 0.03 & 0.43 & Moderate \\
\hline Goeng & 0.19 & 0.25 & 0.15 & 0.03 & 0.62 & Moderate \\
\hline Waekob & 0.17 & 0.25 & 0.15 & 0.05 & 0.63 & Moderate \\
\hline $\begin{array}{l}\text { Sawai } \\
\text { Itepo }\end{array}$ & 0.19 & 0.25 & 0.15 & 0.08 & 0.67 & Moderate \\
\hline Kobe & 0.19 & 0.25 & 0.18 & 0.07 & 0.68 & High \\
\hline Woejerana & 0.17 & 0.25 & 0.15 & 0.05 & 0.63 & Moderate \\
\hline $\begin{array}{l}\text { Lelilef } \\
\text { sawai }\end{array}$ & 0.19 & 0.25 & 0.18 & 0.07 & 0.68 & High \\
\hline $\begin{array}{l}\text { Lelilef } \\
\text { Waibulen }\end{array}$ & 0.19 & 0.25 & 0.20 & 0.08 & 0.72 & High \\
\hline Kulo Jaya & 0.17 & 0.25 & 0.20 & 0.07 & 0.70 & High \\
\hline Gemaf & 0.17 & 0.25 & 0.18 & 0.07 & 0.67 & Moderate \\
\hline
\end{tabular}

In addition, mapping of the vulnerability index has been done. Reading is the best and easy way to understand the locations with a low and high category. The map shows spatially the location and places directly and detail. The vulnerability map in the study area is shown on Fig. 11. 


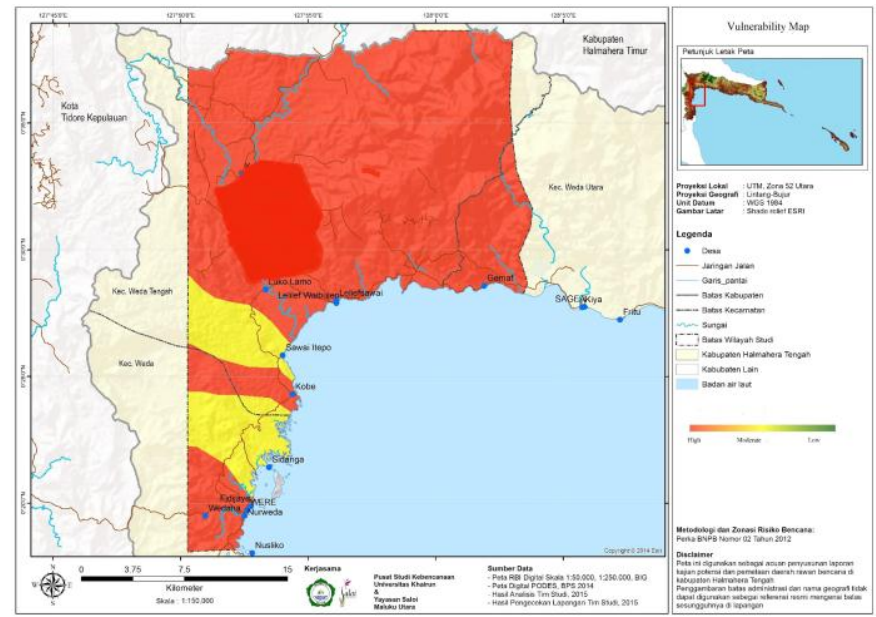

Fig. 11. Vulnerability Index Map in the Study Area.

\section{D) Risk Map}

Flood disaster risk mapping is compiled based on the calculation of each index of flood risk assessment. The mapping of flood risk in the study area is shown in Figure 12. Based on the map, it is seen that almost all the village areas have a flood risk level varies from low to high risk. Low-risk areas are generally located in high altitudes. While high-risk areas are dominates on village areas.

The high risk of flooding in the study area is caused by; firstly, the areas are centrally located to people activities, living, public and critical facilities location, farming area and others activities. Secondly, the high level of risk due to the presence of several rivers and most of the villages in the study area is surrounded by the watershed. Thirdly, lack of capacity from a community and local government in terms of disaster education, availability of early warning system, structured preparedness system, and lack of human resources are the factor that led the high-risk category in study areas.

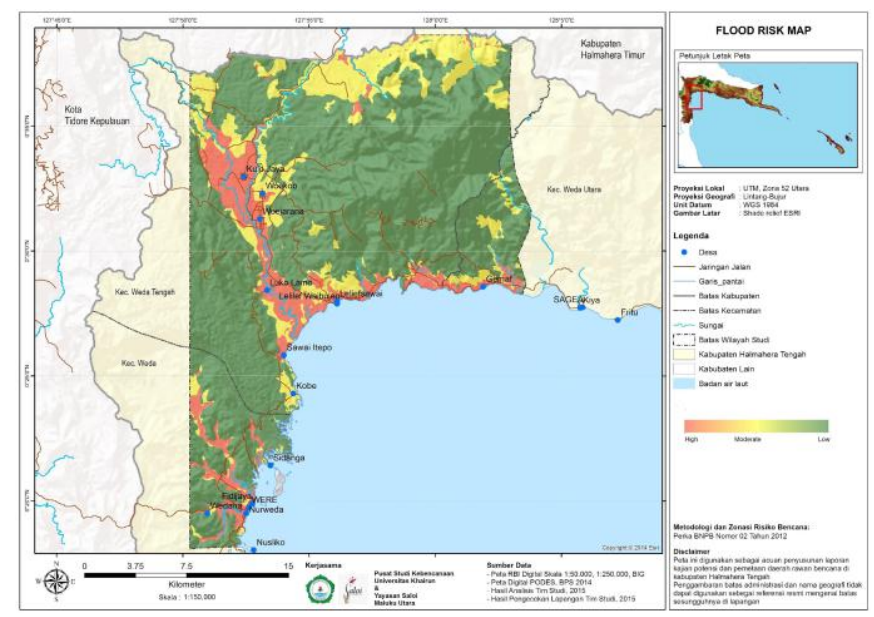

Fig. 12. Flood Risk Map in the Study Area.
Furthermore, the results of disaster risk mapping can inform areas that are potentially affected by the disaster to the extent of the area. In detail, the total area of each village according to the level of flood risk is presented in Table 4. Based on the calculation of the total area, the total area that is potentially affected by the flood disaster is $54956.48 \mathrm{Ha}$. The area with a low-risk level is $40275.48 \mathrm{Ha}(73.3 \%)$, the area with a moderate risk level is $8615.96 \mathrm{Ha}(15.7 \%)$, and an area with a high-risk level of $6065.04 \mathrm{Ha}(11,0 \%)$. From the size of the area, it can be seen that the area with a high level of risk is relatively small compared to the area with low-risk levels.

TABLE IV. $\quad$ RISK LEVELS AND ITS CATEGORY IN STUDY AREA

\begin{tabular}{|l|r|r|r|}
\hline \multirow{2}{*}{ Villages } & \multicolumn{3}{|c|}{ Risk Level (Ha) } \\
\cline { 2 - 4 } & \multicolumn{1}{|c|}{ Low } & Moderate & \multicolumn{1}{c|}{ High } \\
\hline Fidi jaya & 560,52 & 46,14 & 326,38 \\
\hline Gemaf & 8210,15 & 2046,98 & 318,10 \\
\hline Kobe & 1657,52 & 293,96 & 15,62 \\
\hline Kulo Jaya & 2869,66 & 1347,43 & 1183,17 \\
\hline Lelief Sawai & 14014,01 & 3235,33 & 938,95 \\
\hline Lelilef Waibulen & 3447,12 & 496,91 & 985,79 \\
\hline Lukolamo & 35,42 & 22,24 & 188,63 \\
\hline Nurweda & 969,14 & 70,17 & 290,88 \\
\hline Sawai Itepo & 2811,75 & 57,35 & 122,62 \\
\hline Sidanga & 2832,83 & 181,78 & 508,52 \\
\hline Were & 320,02 & 5,97 & 77,52 \\
\hline Woejerana & 1996,88 & 293,30 & 505,17 \\
\hline Woekob & 550,45 & 518,40 & 603,70 \\
\hline Total & $\mathbf{4 0 2 7 5 , 4 8}$ & $\mathbf{8 6 1 5 , 9 6}$ & $\mathbf{6 0 6 5 , 0 4}$ \\
\hline
\end{tabular}

\section{CONCLUSION}

Natural disasters are a consequence of a combination of natural activities (a physical event, such as volcanic eruptions, earthquakes, landslides) with human activities. Lack of human resilience due to lack of management of emergencies, low capacity, and high risk on study area led to increasing of vulnerability. Therefore, the understanding related to disaster risk reduction should be a priority programme by the local government. the programs could be conducted by government such as; provide various resources both budget and human resources for disaster risk reduction activities not only in district level but also to the village level,; increasing the role of community, as well as regulating especially regarding the each mechanisms and each responsibilities, and it is necessary to build a Disaster Risk Reduction forum at the regional level consisting of various stakeholders.

\section{ACKNOWLEDGEMENT}

The authors said thanks to Weda Bay Nickel Company and Regional Disaster Management Agency of Central Halmahera District of as supporter partner in this study. Also thanks to Disaster Study Center Khairun University for supporting data and team. 


\section{REFERENCES}

[1] K. Ali, R.M. Bajracharya, H.L. Koirala, and F. Begum, "A Review of Flood Risk Assessment," Int. J. of Innov. Res. in Sci., Eng. and Tech., vol. 5, pp. 2319-8753, December 2016.

[2] EU Floods Directive, "2007/60/ES of the European Parliament and of the Council on the Assessment and Management of Flood Risks," [Online], Available: http://eur-lex.europa.eu/legal-content/EN/TXT/ PDF/?uriDCELEX:32007L0060\&fromDEN. [Accessed: 23-Aug2018].

[3] Pusat Studi Kebencanaan - Universitas Kahirun, "Kajian Potensi dan pemetaan daerah Rawan bencana di Kabupaten Halmahera Tengah. 2015," Unpublished.

[4] A.M.J. de Kraker, "Flooding in river mouths: human caused or natural events? Five centuries of flooding events in the SW Netherlands, 1500-2000". Hydrol. Earth Syst. Sci., vol. 19, pp. 26732684, 2015.

[5] I.M. Magami, S. Yahaya, and K. Mohammed, "Causes and Consequences of Flooding in Nigeria: A Review," Bio. and Environ. Sci. J. for the Tropics, vol. 11, 2014

[6] G. Schädler, P. Berg, D. Düthmann, H. Feldmann, J. Ihringer, H. Kunstmann, J. Liebert, B. Merz, I. Ott, S. Wagner, "Flood Hazards in a Changing Climate". [Online], Available: https://www.cedim.kit.edu /download/Flood_Hazards_in_a_Changing_Climate.pdf. [Accessed: 13-Aug-2018].

[7] P.M. Kundu, R.L Singo, J.O Odiyo1 and T.R. Nkuna. "Effect of Climate Change on Flood Risk and Sustainable Development in South Africa," 2014 [Digests $6^{\text {th }}$ Int. Conf. on Flood Management, Brazil, 2014].

[8] Badan Perencanaan Pembangunan Nasional. Rencana Aksi Nasional Adaptasi Perubahan Iklim, 2014.

[9] C. Armenakis, E. Xinheng, S. Natesan, R.A. Persad and Y. Zhang, "Flood Risk Assessment in Urban Areas Based on Spatial Analytics and Social Factors," Geosciences, vol. 7, pp. 123, 2017.

[10] S. Zlatanova. T. Ghawanab, A. Kaur, and J.M.M Neuvel, "Integrated Flood Disaster Management and Spatial Information: Case Studies of Netherlands and India," The Int. Archives of the Photogrammetry, Remote Sensing and Spatial Inf. Sci., vol. XL, pp. 8, 2014 [Digests ISPRS Technical Commission VIII Symposium, 09 - 12 December 2014, Hyderabad, India].

[11] A. Gharagozlou, H. Nazari, and M. Seddighi, "Spatial Analysis for Flood Control by Using Environmental Modeling," J. of Geogr. Inf. Syst., vol. 3, pp. 367-372, 2011.

[12] Badan Perencanaan Pembangunan Daerah Kabupaten Halmahera Tengah, "Rencana Tata Ruang Wilayah Kabupaten Halmahera Tengah tahun 2009-2029," 2008.

[13] Biro Pusat Statistik Kabupaten Halmahera Tengah, "Halmahera tengah dalam Angka," 2015.

[14] M. Pelling, "Visions of Risk: A Review of International Indicators of Disaster Risk and its Management," [Online], Available: https://www.unisdr.org/files/2549_visionsofrisk.pdf. [Accessed: 10Jul-2018].

[15] T. Ologunorisa, "An assessment of flood vulnerability zones in the niger delta, Nigeria," Int. J. Environ. Studies, vol. 61, pp. 31-38, 2004.

[16] W. Kron, "Flood Risk $=$ Hazard $・$ Values $・$ Vulnerability," J. Water Int., vol. 30, pp. 58-68, 2005.

[17] A. Pistrika, and G. Tsakiris, "Flood risk assessment: a methodological framework," [Digests Water Resources Manag.: New Approaches and Tech., European Water Resources Association, Chania, Crete Greece, 14-16 June 2007].

[18] Badan Nasional Penaggulangan Bencana. Peraturan Kepala BNPB Nomor 2 tahun 2012 tantang Pedoman Umum Pengkajian Risiko Bencana.

[19] W.B. Nikel, "Laporan Tahunan Curah Hujan di Stasiun Wosea," Unpublished
[20] Badan Penanggulangan Bencana Daerah, Provinsi Maluku Utara, “Kajian Risiko bencana Maluku Utara 2016-2020,” 2015.

[21] B. Nurgianto, "Akibat Banjir, RSUD Weda Halmahera Tengah Masih Lumpuh," [Online], Available: https://nasional.tempo.co/read/356960 /akibat-banjir-rsud-weda-halmahera-tengah-masih-lumpuh/full\&view $=$ ok. [Accessed: 10-Jul-2018].

[22] Patrikaki.O, Kazakis.N, Kougias.I, Patsialis.T, Theodossiou.N, and Voudouris. K. "Assessing Flood Hazard at River Basin Scale with an Index-Based Approach: The Case of Mouriki, Greece". Geosciences 2018, 8, 50; doi:10.3390/geosciences 8020050

[23] L.H. Gunderson, and C.S Holling, "Panarchy: Understanding Transformation in Human and Natural Systems," Washington DC: Island, 2001.

[24] M.A. Janssen, M.L. Schoon, W. Ke, K. Bo"rner, "Scholarly networks on resilience, vulnerability and adaptation within the human dimensions of global environmental change," Global Environmental Change, vol: 16, pp. 240-252, 2006.

[25] W.N. Adger, and A. Winkels, "Vulnerability, poverty, and sustaining well-being," Handbook of sustainable development, $2^{\text {nd }}$ ed., Edward Elgar Publishing Company, 2006.

[26] UN. ESCAP, "Guidelines on participatory planning and management for flood mitigation and preparedness," Water resources series, vol. ix, 2003.

[27] E.C Penning-Rowsell, P. Floyd, D. Ramsbottom, S. Surendran, "Estimating injury and loss of life in floods: a deterministic framework," Nat. Hazards, vol. 36, pp. 43-64, 2005.

[28] C. Small, R.J. Nicholls, "A global analysis of human settlement in coastal zones,” J. Coast Res., vol. 19, pp. 584-599, 2003.

[29] L. Bijlsma, C.N. Ehler, R.J.T. Klein, S.M. Kulshrestha, R.F. McLean, N. Mimura, R.J. Nicholls, L.A. Nurse, Perez, H. Nieto, E.Z. Stakhiv, R.K. Turner, and R.A. Warrick, "Coastal zones and small islands," in Climate Change adaptations and mitigation of climate change: scientific-technical analyses, Cambridge: Cambridge University Press, pp. 289-324, 1995. 